\title{
NÉVÉ-CAPPED SNOW PILLARS RESULTING FROM ABLATION ON TETON GLACIER, WYOMING
}

\author{
By Roald Fryxell \\ (Laboratory of Anthropology, Division of Archaeology and Geochronology, Washington \\ State University, Pullman, Washington, U.S.A.)
}

\begin{abstract}
Névé-capped snow pillars found on Teton Glacier in August 1956 were formed in the same manner as the ice cones of glacier tables, the névé acting in this instance as the protective cover usually provided by slabs of rock. Measurements of the largest pillar indicate a minimum ablation of $6 \cdot 5 \mathrm{ft}$. ( $\left(\mathrm{r} \cdot 9^{8} \mathrm{~m}\right.$.) of snow on the surface of Teton Glacier for that summer up to 7 August, and suggest an average rate of snow wastage of $\mathrm{I} \cdot 5$ in. $(3.8 \mathrm{~cm}$.) per day during this time. The pillars appear to have been produced by ablation through melting due primarily to direct radiation but supplemented by indirect radiation and conduction-convection influenced by air currents moving across the surface of the glacier.
\end{abstract}

RÉsumé. Observation de piliers de neige surmontés de névé, formes d'ablation sur le Teton Glacier, Wyoming. Des piliers de neige surmontés de névé trouvés sur le Teton Glacier en août 1956 se présentent de la même manière que les tables glaciaires, le névé jouant le même rôle protecteur que la plaque de roche. Des mesures des plus grands piliers donnent une ablation minimum de $1,98 \mathrm{~m}$ de neige de cet été jusqu'au 7 août, et une ablation moyenne de $3,8 \mathrm{~cm}$ par jour pour cette période. Les piliers semblent être formés par ablation par fonte due principalement par radiation directe, augmentée par radiation indirecte et conduction-convexion influencée par les masses d'air se mouvant sur la surface du glacier.

Zusammenfassung. Firngekrönte Schneesäulen, erzeugt von der Ablation auf dem Teton Glacier, Wyoming. Firngekrönte Schneesäulen die am Teton Glacier im August 1956 gefunden wurden, entstammen demselben Entstehungsprozess wie die Eiskegel von Gletschertischen, wobei hier der Firn als jene Schutzdecke wirkt, die gewöhnlich durch Felsplatten gebildet wird. Messungen an den höchsten Säulen zeigen eine Mindestablation von $6,5^{\prime}(1,98 \mathrm{~m})$ Schnee auf der Oberfläche des Teton Glacier bis zum 7 August jenes Sommers, woraus sich ein Mittelwert von $1,5^{\prime \prime}(3,8 \mathrm{~cm})$ Schneeabschmelzung pro Tag in dieser Zeit ergibt. Die Säulen sind anscheinend durch Schneeablation vor allem unter der Einwirkung direkter Strahlung gebildet worden, die jedoch durch indirekte Strahlung und durch konduktiv-konvektive Wärme verstärkt wurde, deren Ausmass von den Luftströmungen über der Gletscheroberfläche abhängt.

REPORTs of unusual "snow pillars" observed by climbing parties crossing Teton Glacier in Grand Teton National Park, Wyoming, were investigated on 7 August 1956. At that time one large snow pillar (Fig. I) and six much smaller ones were located on the glacier at an altitude of about $10,500 \mathrm{ft}$. $(3,200 \mathrm{~m}$.), just below the steep crevassed section of the glacier known as "The Icefall" and to the left or south side of the avalanche track extending down from Gunsight Notch.

All seven of the snow pillars were on a gentle, almost level, snow slope within a roughly circular area $40 \mathrm{ft}$. (12 m.) across, the smaller ones being scattered to the south and slightly down-slope of the large pillar. This large pillar (Figs. I and 2) was capped by a block of névé $4 \mathrm{ft}$. ( $\mathrm{I} \cdot 2 \mathrm{~m}$.) across and $\mathrm{I} 8 \mathrm{in}$. $(45 \mathrm{~cm}$.) thick, separated from the soft snow beneath by an irregular surface of dirty snow which, when chopped open with an ice axe, yielded a yellowish aspen leaf. The snow below this line, though weakly layered, blended imperceptibly with that of the surrounding surface and clearly was a part of the preceding winter's precipitation. The large pillar in over-all dimensions was slightly more than $8 \mathrm{ft}$. $(2.4 \mathrm{~m}$.) high; strongly asymmetrical, the maximum diameter at its elliptical base measured $\mathrm{I} 2$ to $\mathrm{I} 4 \mathrm{ft}$. ( 3.6 to $4.2 \mathrm{~m}$.) along its east-west axis, the pillar itself rising abruptly on the east and sloping gently toward the west. The smaller pillars, including two which lacked the névé cap, ranged from $\mathrm{I} \cdot 5$ to $4 \mathrm{ft}$. $(0.45$ to $\mathrm{I} \cdot 2 \mathrm{~m}$.) in height and all showed the same orientation and asymmetrical profile as the large pillar.

\section{Genesis}

The asymmetrical appearance of the snow pillars is not surprising, as it duplicates that of pedestals supporting glacier tables which frequently develop on Teton Glacier (Fryxell, i 933, p. 739; 1935, p. 389 93). But despite the resemblance of these snow pillars to the pedestals left 


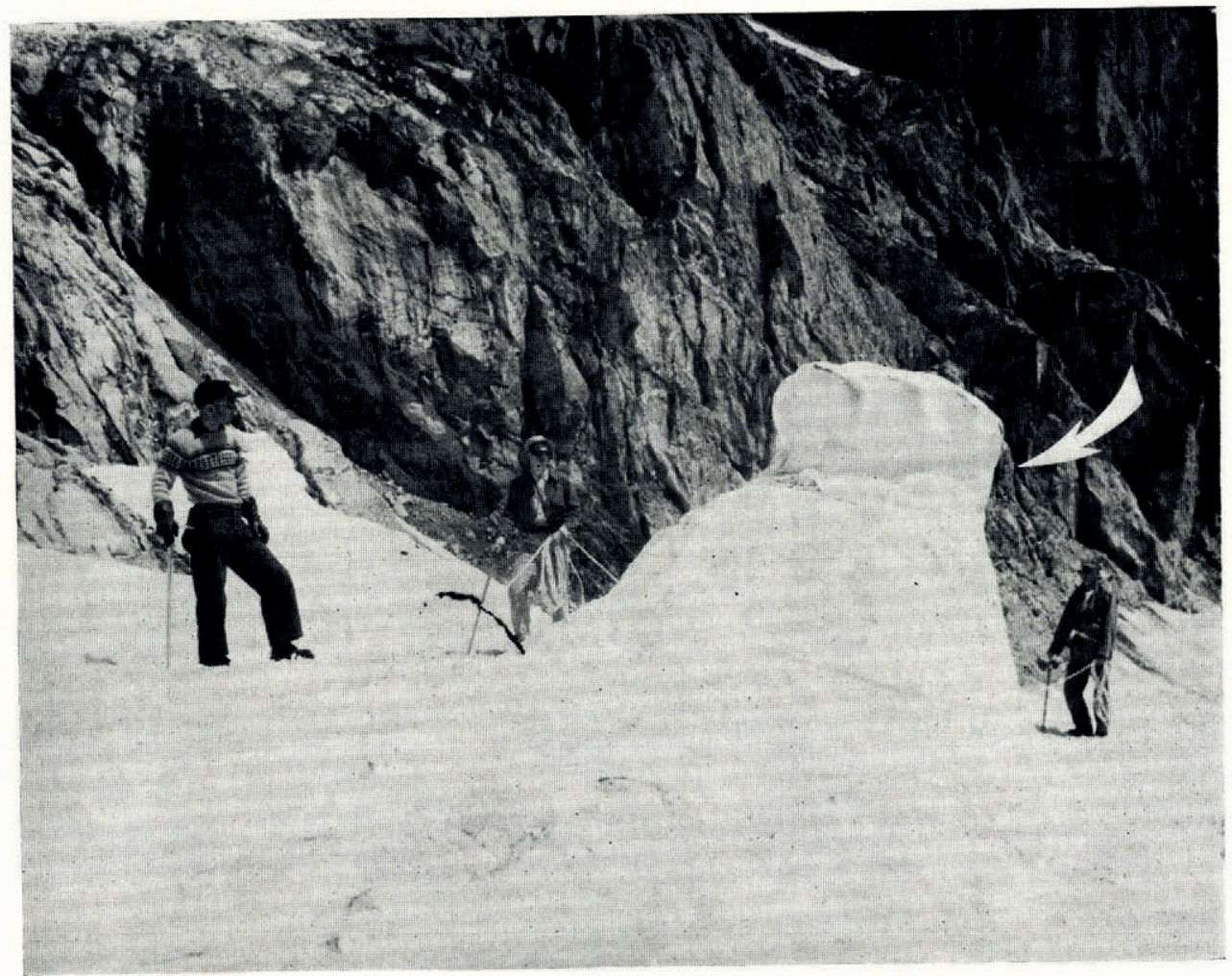

Fig. I. Large snow pillar on Teton Glacier, 7 August 1956. Note abrupt slope facing east-south-east in contrast to the gentle slope and overhanging névé cap on opposite side. Arrow indicates contact between névé cap and soft snow beneath. Rocks in background are the southern cliffs of Mount Owen

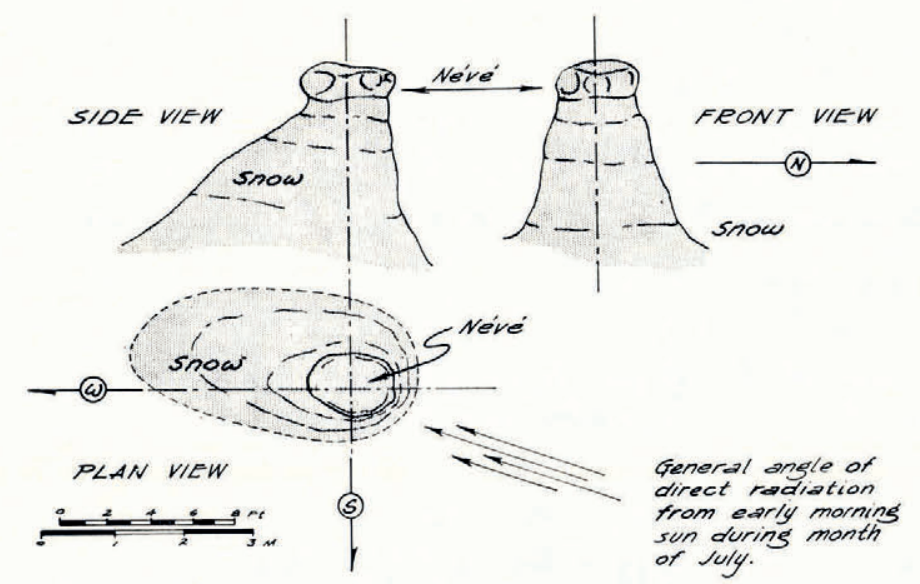

Fig. 2. Field sketch of large snow pillar, showing relationship of asymmetry to the general angle of direct radiation from early morning sun. Later in the day, this part of Teton Glacier is shaded by the north face of Grand Teton (Fig. 3) 
by large boulders toppling from glacier tables, there were no rocks large enough to have sheltered pillars of this size visible within 0.25 miles $(0.4 \mathrm{~km}$.). Any crevasses large enough to have swallowed such a boulder were at this time bridged and deeply buried beneath the snow on which the pillars had developed.

On the other hand, the pillars obviously were products of the same process by which glacier tables are formed, the slowly wasting névé acting in this case as the protective cap necessary to shade the soft snow beneath from the sun. Several factors appear to have contributed to this discrepancy in rates of ablation:

I. The whiteness of the névé cap would be ideally suited for the dual role of reflector and insulator, and the resulting lack of heat absorbed and transmitted would maintain high albedo for the névé cap, while shielding the snow beneath it. The effectiveness of this shield is reinforced because of the inherently higher reflectivity of the névé (Hubley, r955, p. 562) and because shelter by this cap is most complete when solar angles are high and albedo of the snow is at a minimum (Hubley, r 955).

2. Icy layers behave as resistant strata in comparison with snowy ones because of the greater water content per unit volume locked up in them, and the correspondingly greater amounts of heat required to melt them (Amstutz, 1958, p. 31 I). This is true also for compact granular névé. Sharp (personal communication) notes that "névé of density 0.5 or $0.6 \mathrm{~g} . / \mathrm{cm} .^{3}$, for example, requires twice as much heat for melting as snow at 0.25 to $0.3 \mathrm{~g} . / \mathrm{cm} .{ }^{3}$ density". Ablation is accelerated by air in motion and many minor drainage winds on Teton Glacier are confined to within a few feet of the surface. Exaggeration of the difference between snow and névé in resistance to ablation would result in continued lowering of the snow surface left, the névé blocks being stranded higher and higher beyond reach of these eddies. Undercutting of the west edge of the névé block may have resulted in this way.

Certainly a large block of névé would be required to outlast the wasting of nearly $7 \mathrm{ft}$. $(2 . \mathrm{I} \mathrm{m}$.) of snow, but fresh breaks in old snow or névé noted at $12,000 \mathrm{ft}$. (3,66o m.) along the Randkluft and bergschrund just below Gunsight Notch were large enough to have provided the necessary quantity of material. This interpretation is somewhat strengthened by the distribution of the smaller pillars, which were scattered to one side of the large pillar, opposite the avalanche track, as though the fragments of névé which gave rise to them had rolled or slid there after breaking from the larger block when it came to a stop. Because the pedestals beneath these smaller névé blocks are not as high as that of the large pillar, they may also represent "second-generation" pillars under fragments displaced by undercutting and collapse of a larger cake of névé. Such shedding of undercut parts would eliminate overbalancing. This may explain failure of the névé blocks to show the common southerly tilt of rocks capping glacier tables in the Northern Hemisphere (Sharp, 1949, p. 303). For this reason, it also is unlikely that the névé blocks had shifted position laterally in the manner of boulders capping glacier tables (Fryxell, I933; Sharp, I949).

Evidence of the recency with which the névé came to rest at the spot occupied by the large pillar was supplied by the aspen leaf found beneath it, which definitely did not date back to the previous summer. The two pillars lacking névé caps probably lost them through ablation and they themselves were wasting rapidly away. Two other $18 \mathrm{in}$. $(45 \mathrm{~cm}$.) humps in the snow nearby may have had the same origin.

\section{Nature of Ablation}

No ablation studies have yet been made of glaciers in the Teton Range, and therefore only general conclusions may be drawn as to the nature of wasting involved during development of the snow pillars. Information available at present may be summarized as follows:

Sheltered to the south and west by the great north face of the Grand Teton (Fig. 3), the section of Teton Glacier on which the snow pillars were found can receive direct sunlight for 
only a short time each day, mainly during the morning hours when the rays of the sun are at a low angle and relatively inefficient. Nevertheless, the near-vertical eastern face of the pillars is testimony to the importance of direct radiation as a cause of ablation, however oblique the angle of the sun. Quite naturally, the elliptical plan view of the snow pillars reflects these conditions; even the southerly slant of the sun's rays in a northern latitude resulted in asymmetric development noticeable on the large snow pillar (Fig. 2), where the point of greatest wasting was at the south-east. By noon or shortly after, the sun has moved behind the north face and the location of the snow pillars is in shadow.

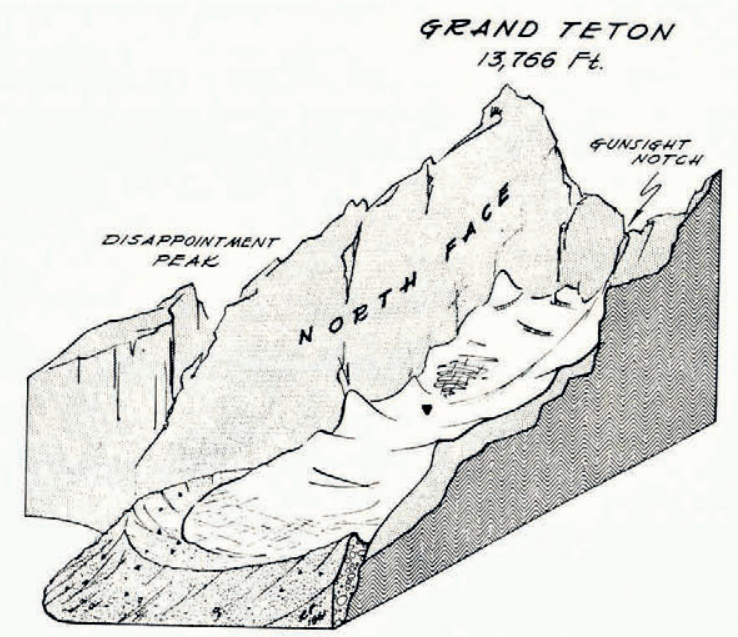

Fig. 3. Schematic block diagram (based on field sketches and pholographs) showing the physiographic position of Teton Glacier; the black triangle on the glacier near the base of the north face indicates the location of the snow pillars examined in 1956 The diagram is not to scale

Shadow, however, even under cloudy conditions, does not necessarily put a halt to ablation (Wallén, 1948; Hoinkes, I955; Hubley, I955; LaChapelle, I955). On a sunny day the amount of noticeable light and heat transmitted by indirect radiation from the sky above and reflection from the sunlit southern walls of Mount Owen is not small and, if the sky is not heavily overcast, even the deepest shadows on the glacier or the north face can be surprisingly bright on cloudy as well as sunny days. Thus indirect radiation and atmospheric temperatures play an important role in controlling ablation of the snow in sheltered parts of the glacier, and probably had a dominant effect on parts of the snow pillars hidden from direct radiation.

As mentioned previously, an additional factor controlling ablation of the snow pillars is the movement of air currents across the surface of the glacier. The acceleration of melting by moving air has been demonstrated by Hoinkes (r954), and similar shifting of air currents probably induces conduction-convection ablation on Teton Glacier. On a small scale these currents may be mere eddies or breezes set in motion by local variations in temperature; on a much larger scale they result from changes in weather as well as from almost daily surges of wind due to the sharp temperature change at sundown. Here it becomes evident that if these daily katabatic winds are important factors in the loss of volume, particularly snow, from the surface of the glacier, they represent a means of ablation active not only during the day but after dark as well.

More unusual winds also have been observed while crossing Teton Glacier but their frequency and probable net effect are much less. As the cold higher levels of air sink down at dusk into Jackson Hole, the warm air of the valley begins to rise, sweeping up the eastern slopes 
of the peaks and across their flanks, occasionally with such force that fragments of conversation in the camp grounds at Jenny and String Lakes can be heard in the mountains with startling clarity as far as two or even three thousand feet above the valley floor. Such a blast of warm dry air, blowing across the snow fields in its path like a miniature chinook or foehn in reverse, undoubtedly results in a very significant amount of ablation; though canyons normally serve as channels for the rush of descending cold air, at least occasionally the warm updrafts are funneled up Glacier Gulch and along the length of Teton Glacier. Probably their effectiveness is most pronounced at the lower end of the glacier.

Ablation by rapid evaporation or sublimation seems unlikely to be an important factor at this locality. Although Matthes (1934, p. 384) suggested that evaporation is the principal type of ablation on high-altitude snow banks and correlated the development of suncups and penitentes with such conditions, subsequent studies (Lliboutry, I954; Amstutz, 1958) have made it clear that the development of penitentes is a process far more complex than Matthes supposed. Some evidence remains to indicate rapid evaporation and sublimation can be a significant means of ablation at high altitudes (Lliboutry, 1954, p. 332) and high latitudes (Loewe, I956, p. 726), but Hoinkes (1955, p. 499) recorded negligible amounts of evaporation (usually less than I per cent of total ablation) from ice on glaciers in the Alps. Kehrlein and others (Sharp, I95I ; personal communication from R. P. Sharp) measured the melt-water yield of snow at sites in the Sierra Nevada and obtained data suggesting condensation instead. No work of this sort has been done in the Tetons.

\section{Rate of Ablation}

In the complete absence of any quantitative data or estimates of the rate of ablation on the surface of Teton Glacier, the large snow pillar becomes of interest as an indicator of the minimum rate of ablation at this locality during the summer of 1956 . The last heavy snowfall of the previous season was on 15 June and, since the avalanche scar below Gunsight Notch was observed a week later during an ascent of Mount Owen, it is assumed the névé blocks capping the pillars avalanched into place by or shortly after 15 June. The possibility that avalanche blocks of névé might have been incorporated into the snow at a still earlier datethus increasing both amount and rate of ablation - cannot be ruled out, but it seems unlikely in view of the freshness of the avalanche scar at Gunsight Notch and the aspen leaf located beneath the névé cap. If this is correct, the ablation necessary to produce the large pillar would amount to $7^{8} \mathrm{in}$. ( $\mathrm{I} \cdot 9^{8} \mathrm{~m}$.) in 54 days - an average of slightly less than $\mathrm{I} \cdot 5 \mathrm{in} .(3 \cdot 8 \mathrm{~cm}$.)/day. Two methods were used in an attempt to gain an idea of the duration of effective wasting on the surface of Teton Glacier during the 1956 season:

I. Utilizing the known storm dates of $5_{5}$ June and 30 August to bracket the effective ablation period, assuming the heavy snowfalls on those dates to have offset wasting before and after this time.

2. Plotting cloud cover together with a graph of the mean daily temperatures recorded at Park Headquarters near Moose, and the temperature lowered by $3 \cdot 3{ }^{\circ} \mathrm{F}$. $\left(\mathrm{I} \cdot 8^{\circ} \mathrm{C}\right.$.) for each $\mathrm{I}, 000 \mathrm{ft}$. (305 m.) altitude, the approximate rate of normal temperature drop with elevation suggested by Trewartha (I943, p. I6 I) needed to attain the elevation of Teton Glacier.

Results of the two approaches coincide, and on such a basis the minimum period of ablation for 1956 would seem to be 75 days, from i 5 June to 30 August (Fig. 4) with a minimum wasting (at the rate of $\mathrm{I} \cdot 5 \mathrm{in}$. or $3.8 \mathrm{~cm}$./day) of $9 \mathrm{ft} .4 \mathrm{in}$. $(2 \cdot 85 \mathrm{~m}$.). The effects of ablation preceding or following this period are not considered, since surely it must have proceeded at a reduced rate, and there is no means of estimating how much wasting would have been offset by periodic snowstorms and flurries. However, a possible maximum duration of 150 days, extending from 
the middle of May to the middle of October, is suggested for the effective ablation period by the projected temperature curve in Figure 4. The validity of these figures is best judged through comparison with other data, though none exist for Teton Glacier itself.

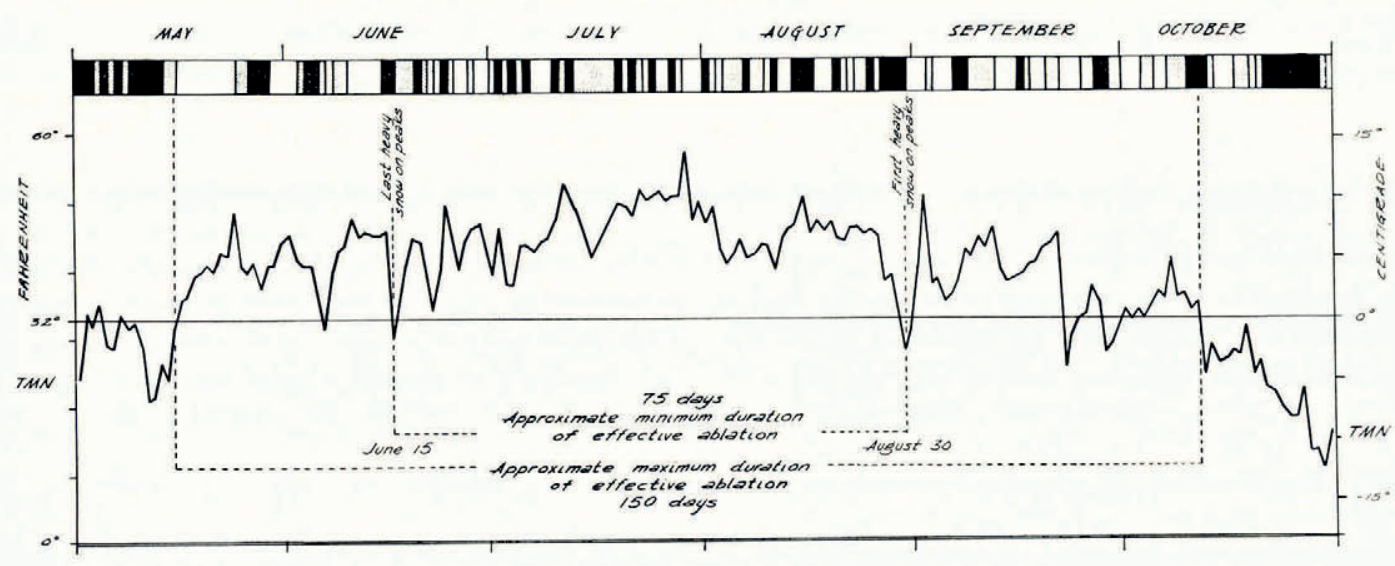

Fig. 4. Cloud cover chart and projected temperature curve for Teton Glacier for the summer of 1956 , with inferred limits of the effective ablation period. Areas in black at top of chart indicate heavy overcast, those in grey represent days which were partly cloudy, and white areas record clear days. Daily mean temperatures (T.M.N.) have been lowered $13^{\circ} \mathrm{F}$. ( $\left(7 \cdot 3^{\circ} \mathrm{C}\right.$.) , an arbitrary rate of $3 \cdot 3^{\circ} \mathrm{F}$. $\left(\mathrm{I} \cdot 8^{\circ} \mathrm{C}\right.$.) for each $\mathrm{I}, 00 \mathrm{ft}$. (305 m.) above the valley floor needed to attain the elevation of Teton Glacier. Weather records were taken by National Park Service personnel at Park Headquarters, Moose, Wyoming, at an elevation of $6,627 \mathrm{ft}$. $(2,020 \mathrm{~m}$.)

\section{Comparison with OTHER DATA}

The nearest location for which ablation data are available appears to be Dinwoody Glacier in the Wind River Range of Wyoming, some 75 miles (120 km.) to the south-east of the Tetons. A cirque glacier on the north-east flank of the continental divide near Gannett Peak, Dinwoody Glacier is nearly 2 miles $(3.2 \mathrm{~km}$.) wide, $\mathrm{I} \cdot 5$ miles $(2.4 \mathrm{~km}$.) long and extends downward from $\mathrm{I}_{3}, 200$ to $\mathrm{I}, 200 \mathrm{ft}$. (4,025 to $3,4 \mathrm{I} 5 \mathrm{~m}$.). Hence, it lacks the sheltered position of Teton Glacier, and unfortunately terminates above the elevation at which the Teton snow pillars were formed.

During the $195^{\circ}$ field season, ablation studies were conducted by Meier at eight localities on Dinwoody Glacier. At his lowest stake, placed near the snout of the glacier at about I I ,230 ft. (3,425 m.) (Meier, unpublished, p. 99), he obtained daily readings of surface snow loss ranging from $0_{4} \cdot 4$ in. ( $1 \cdot 02 \mathrm{~cm}$.) to a maximum of $2 \cdot 6$ in. $(6 \cdot 6 \mathrm{~cm}$.) (Meier, unpublished, p. I05-06). The figures presented below are compiled from Meier's observations on Dinwoody Glacier for comparison with those suggested by study of the large snow pillar on Teton Glacier in 1956 :

\section{Dinwoody Glacier, $195^{\circ}$}

Period of study: 25 July to 5 September.

Duration of observations: 42 days.

Total observed ablation at I I,230 ft. $(3,425 \mathrm{~m}):$.80 in. $(2.03 \mathrm{~m}$.$) of firn.*$

Average rate of ablation: $1 \cdot 9$ in. $(4 \cdot 8 \mathrm{~cm}$.) of firn per day.

* Although the usage of firn is not defined in Meier's text, it appears to include snow from the preceding winter as well as earlier seasons. Since snow examined on Teton Glacier did not date past the preceding winter and had not yet become noticeably granular, it is not here referred to as firn though much of the material involved in the two studies is presumed to be the same. 
Teton Glacier, ${ }_{1956}$

Period covered by study: i 5 June to 7 August.

Duration of ablation covered by study: 54 days.

Total ablation indicated by large snow pillar: 78 in. ( $1 \cdot 98 \mathrm{~m}$.) of snow.

Suggested average rate of ablation: $\mathrm{I} \cdot 44$ in. $(3 \cdot 65 \mathrm{~cm}$.) of snow (rounded to $\mathrm{I} \cdot 5 \mathrm{in}$. $(3.8 \mathrm{~cm}$.$) in text) per day.$

Comparison of these data shows the average daily ablation rate recorded by Meier for I950 was fully one-third larger than that suggested for Teton Glacier in 1956, but even so it represents a net difference of less than $0.5 \mathrm{in}$. ( $\mathrm{I} \cdot 27 \mathrm{~cm}$.) (actually $\mathrm{I} \cdot \mathrm{I} 5 \mathrm{~cm}$.). Precise evaluation of data from these localities is somewhat difficult in view of the difference in exposure mentioned previously, and the fact that observations were made during different seasons. Meier (unpublished, p. Iog) regarded the 1950 season as unusual due to low temperatures and a shorter ablation period than normal. The same may be said for 1956 in the Tetons in that the August snowstorm ending the effective ablation period was, in the writer's experience, both unusually early and unusually heavy. Unfortunately no weather records are available to supplement the Wind River data.

The ablation figures submitted for Teton Glacier are at best, of course, minimum approximations, and as such inevitably are subject to several serious criticisms. First of all, the above figures are not the products of precise measurements. Very likely the figure of ${ }_{\mathrm{I}} \cdot 5 \mathrm{in} .(3 \cdot 8 \mathrm{~cm}$.) ablation per day is too low for much of the period during which the pillar was formedparticularly for late June, when exposure to direct radiation would have been most prolonged, and for late July, when atmospheric temperatures were highest. The same figure also may be too low for cold, heavily clouded days earlier or later in the season. R. C. Anderson (personal communication) suggested a further source of error due to lowering of the pillar itself through re-orientation or recrystallization of snow beneath the névé cap in response to temperature and vapor pressure changes. Hubley (r954) and LaChapelle (r959) have demonstrated the distortion possible for ablation values due to these effects. However, on the basis of his own observations made in the Front Range of the Rockies west of Denver, Anderson has regarded the ablation rate indicated for Teton Glacier as being in the right order of magnitude. Snow banks examined by him, and situated in partially exposed locations at I I, ooo ft. (3,355 m.), were wasting at rates between 2 and 3 in. ( 5 and $7.6 \mathrm{~cm}$.)/day.

More seriously, the reliability of defining the duration of effective ablation on the basis of temperature curves projected from the valley floor is problematical, even though correlation between this curve and the known factors of cloud cover and storm dates is remarkably good. The storm dates themselves probably are the most valid criterion for establishing the effective ablation period. Since the chronology of events in development of the snow pillar is reasonably clear, it seems possible to reconcile the small figure of minimum ablation obtained when one considers the extremely sheltered position of the pillars in the cirque housing Teton Glacier. What little direct radiation reaches this section of the glacier early in the summer dwindles after 2 I June with the southward shift of the sun following the summer solstice and, as indicated earlier, direct radiation seems to have played the dominant role in causing ablation in the vicinity of the pillars.

\section{Acknowledgements}

Thanks are due Mark F. Meier for the generous loan of his unpublished thesis and included data to which reference is made in this report; to the United States National Park Service, F. Douglas McLaren and the late Ernest K. Fields, through whose courtesy meteorological records were obtained; and to Richard C. Anderson and Robert P. Sharp for their careful criticisms and constructive discussions of the manuscript.

MS. received 27 November 1964 


\section{REFERENCES}

Amstutz, G. C. 1958. On the formation of snow penitentes. Fournal of Glaciology, Vol. 3, No. 24, p. 304-09, 31 1.

Fryxell, F. 1933. The migration of superglacial boulders. Fournal of Geology, Vol. 41, No. 7, p. 737-47.

Fryxell, F. 1935. Glaciers of the Grand Teton National Park of Wyoming. Fournal of Geology, Vol. 43, No. 4, p. $38 \mathrm{I}-97$.

Hoinkes, H. C. 1954. Der Einfluss des Gletscherwindes auf die Ablation. Zeitschrift für Gletscherkunde und Glazialgeologie, Bd. 3, Ht. 1, p. 18-23.

Hoinkes, H. C. 1955. Measurements of ablation and heat balance on alpine glaciers. Fournal of Glaciology, Vol. 2, No. 17 , p. $497^{-501}$.

Hubley, R. C. I954. The problem of short period measurements of snow ablation. Journal of Glaciology, Vol. 2, No. 16 , p. $437-40$.

Hubley, R. C. 1955. Measurements of diurnal variations in snow albedo on Lemon Creek Glacier, Alaska. Journal of Glaciology, Vol. 2, No. 18, p. 56o-63.

LaChapelle, E. R. I955. Ablation measurement studies. American Geographical Society. Funeau Ice Field Research Project. Progress Report.

LaChapelle, E. R. 1959. Errors in ablation measurements from settlement and sub-surface melting. Fournal of Glaciology, Vol. 3, No. 26, p. 458-67.

Lliboutry, L. 1954. The origin of penitents. Fournal of Glaciology, Vol. 2, No. 15, p. 33 1-38.

Loewe, F. 1956. Notes on firn temperatures and ablation in MacRobertson Land, Antarctica. Fournal of Glaciology, Vol. 2, No. 20, p. 725-26.

Matthes, F. E. 1934. Ablation of snowfields at high altitudes by radiant solar heat. Transactions of the American Geophysical Union, 1934, Pt. 2, p. 38o-85.

Meier, M. F. Unpublished. Glaciers of the Gannett Peak-Fremont Peak area, Wyoming. [M.Sc. thesis, State University of Iowa, 1951.]

Sharp, R. P. 1949. Studies of superglacial debris on valley glaciers. American fournal of Science, Vol. 247, No. 5, p. $289-315$.

Sharp, R. P. 1951. Melting versus evaporation in the Sierra Nevada, California. Fournal of Glaciology, Vol. I, No. Io, p. $5^{83}$. [Letter.]

Trewartha, G. C. 1943. An introduction to weather and climate. New York, McGraw-Hill Book Co., Inc.

Wallén, C. C. 1948. Glacial-meteorological investigations on the Kårsa glacier in Swedish Lappland, 1942-1948. Geografiska Annaler, Årg. 30, Ht. 3-4, p. 451-672. 